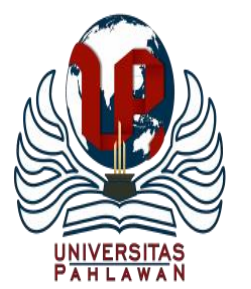

\author{
Jurnal Abdidas Volume 1 Nomor 5 Tahun 2020 Halaman 407 - 412 \\ JURNAL ABDIDAS \\ Community Development Service on Educational and Health Sciences \\ http://abdidas.org/index.php/abdidas
}

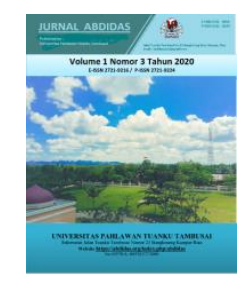

\title{
Bantuan Sosial dan Edukasi Kesehatan bagi Masyarakat Pesisir yang Terdampak Sosial- Ekonomi Selama COVID-19
}

\author{
Husni Mubarak ${ }^{1}$, M Fajar Anugerah ${ }^{2}$, Puspa Ningrum ${ }^{3}$, Tyagita Widya Sari $^{4}$ \\ Universitas Abdurrab, Pekanbaru, Indonesia ${ }^{1,2,3,4}$ \\ E-mail : husni.mubarak@univrab.ac.id ${ }^{1}$ fajar.anugerah@univrab.ac.id ${ }^{2}$ puspa.ningrum@univrab.ac.id ${ }^{3}$ \\ Tyagita.ws@univrab.ac.id ${ }^{4}$
}

\begin{abstract}
Abstrak
Pandemi COVID-19 telah berdampak pada masyarakat pesisir di wilayah semua di Provinsi Riau terkhusus di Kabupaten Bengkalis yang mengalami keterpurukan sosial ekonomi selama COVID-19. Daya tawar hasil panen di laut dan di ladang mengalami penurunan drastis. Situasi ini membuat masyarakat pesisir mengalami kesulitan dalam menjalani hidup. Persoalan ini menarik untuk dikaji dan menjadi dasar dalam melakukan pengabdian masyarakat dalam bentuk bantuan sosial dan pendidikan kesehatan. Kegiatan pengabdian ini bertujuan untuk memberi bantuan sosial dan pendidikan kesehatan kepada masyarakat pesisir. Kegiatan bantuan sosial dan pendidikan kesehatan dilakukan agar masyarakat pesisir bisa terbantu secara sosial ekonomi pada masa pandemi dan kesadaran kritisnya tumbuh terkait bahaya COVID-19. Kegiatan ini juga bertujuan menumbuhkan kesadaran masyarakat akan pentingnya perilaku hidup sehat dan bersih (PHBS). Dengan menambah asupan makanan yang cukup, tubuh mereka memiliki imunitas yang baik sehingga bisa bertahan dari serangan virus. Hasil kegiatan menunjukkan adanya peningkatan kesadaran masyarakat pesisir akan pentingnya memelihara kesehatan. Bantuan sosial yang diberikan juga membantu meningkatkan asupan gizi sehingga menjaga imunitas tubuh di masa pandemik COVID-19.
\end{abstract}

Kata kunci: bantuan sosial, pendidikan kesehatan, dampak sosial ekonomi, COVID-19

\begin{abstract}
The COVID-19 pandemic has affected coastal communities in all areas of Riau Province, especially in Bengkalis district. They experienced a socio-economic downturn during COVID-19. The bargaining power of the crops at sea and in the fields has decreased drastically. This situation makes coastal communities experience difficulties in living. This issue is interesting to study and becomes the basis for conducting community service in the form of social assistance and health education. This service activity aims to provide social assistance and health education to coastal communities. Social assistance and health education activities are carried out so that coastal communities can be helped socially and economically during the pandemic and their critical awareness grows regarding the dangers of COVID-19. This activity also aims to raise public awareness of the importance of healthy and clean lifestyle (PHBS). By increasing adequate food intake, their bodies have good immunity so they can survive virus attacks. The results of the activity show an increase in the awareness of coastal communities about the importance of maintaining health. The social assistance provided also helps increase nutritional intake so as to maintain body immunity during the COVID-19 pandemic.
\end{abstract}

Keywords: social assistance, health education, socio-economic impacts, COVID-19

Copyright (c) 2020 Husni Mubarak, Fajar Anugerah Mubarak, Puspa Ningrum,Tyagita Widya Sari

$\triangle$ Corresponding author

Address : Universitas Abdurrab, Pekanbaru

Email : husni.mubarak@univrab.ac.id

ISSN 2721- 9224 (Media Cetak)

DOI : https://doi.org/10.31004/abdidas.v1i5.84

ISSN 2721- 9216 (Media Online)

Jurnal Abdidas Vol 1 No 5 Tahun 2020 p-ISSN 2721-9224 e-ISSN 2721-9216 


\section{PENDAHULUAN}

Dampak penyebaran pandemi COVID-19 di wilayah Bengkalis adalah menurunnya kualitas dan keadaan sosial ekonomi. Kualitas keadaan sosial ekonomi menurun karena sumber pendapatan dan hasil panen menjadi kurang. Adanya kebijakan pembatasan jam kerja, larangan melakukan aktivitas relasional, termasuk relasi ekonomi menyebabkan kurangnya pendapatan dan hasil panen. Keadaan ini sudah pasti menambah jumlah angka kemiskinan dan keterbelakangan. Bahkan pada titik tentu, kemiskinan dan keterbelakangan ini justru bisa menjadi pemicu akselerasi penyebaran virus ini (Tapung et al., 2020).

Asumsinya, kemiskinan dan keterbelakangan merupakan predisposisi menyebarnya berbagai penyakit, termasuk penyakit menular (Kartono, 2014). Orang miskin dengan kekebalan tubuh yang rendah memiliki derajat kerentanan tinggi tertular penyakit, termasuk virus Corona (Susilo, dkk., 2020). Meskipun fakta lain menunjukkan, negara-negara maju dengan penduduk kaya seperti China, AS, Italia, Inggris, Prancis, dll, ternyata tidak kebal terhadap wabah penyakit menular (Kompas TV, 2020).

Peningkatan kasus yang cukup tajam ini perlu dikendalikan bahkan harus dikurangi. Upaya pencegahan terhadap peningkatan jumlah penderita COVID-19, seperti yang sudah ditetapkan oleh WHO pada bulan Maret 2020 bahwa semua negara didesak untuk melakukan langkah-langkah efektif untuk mengurangi penularan (Beiu et al., 2020). Oleh karena itu, tindakan pencegahan terhadap jenis penyakit menular tersebut wajib dilakukan secepat mungkin yang sesuai dengan Undang-Undang Nomor 6 Tahun 2018 yaitu tentang Kekarantinaan Kesehatan, dimana masyarakat perlu membatasi kegiatan sosial (Telaumbanua, 2020). Penyebaran pada masyarakat pun dapat dikurangi salah satunya dengan menjaga kebersihan tangan secara rutin dan upaya penggunaan masker(Greenhalgh et al., 2020). Hal ini perlu dilakukan karena COVID19 dapat dengan mudah ditularkan melalui jalur pernapasan (tetesan dari orang yang terinfeksi, melalui batuk atau bersin) dan melalui kontak dengan permukaan yang terkontaminasi. Seperti yang sudah dilakukan oleh masyarakat China, bahwa penggunaan masker sudah menjadi kewajiban yang harus diterapkan (Matthay et al., 2020). Atas dasar itulah, penulis bersama mahasiswa serta berbagai pihak melakukan inisiatif untuk melakukan kegiatan pengabdian ini dengan judul kegiatan Bantuan Sosial Dan Edukasi Kesehatan Bagi Masyarakat Pesisir Yang Terdampak Sosial-Ekonomi Selama Patogenesis COVID-19.

Kecamatan Bengkalis merupakan salah satu kecamatan yang berada dalam wilayah administrasi Kabupaten Bengkalis. Kota Bengkalis merupakan Ibukota Kab. Bengkalis yang berada di wilayah Kecamatan Bengkalis. Apabila dilihat dari segi geografis, wilayah Kecamatan Bengkalis mempunyai letak yang sangat strategis dan memiliki sarana dan pra sarana yang memadai juga prospek untuk lebih berkembang. Berdasarkan alasan itulah maka pusat pemerintahan Kabupaten Bengkalis ditetapkan di Kecamatan Bengkalis. Adapun perbatasan wilayah Kecamatan Bengkalis 
adalah sebagai berikut (Pemerintah Kabupaten

Bengkalis, 2019)

1. Sebelah utara berbatasan dengan Kecamatan Bantan dan Selat Melaka.

2. Sebelah selatan berbatasan dengan Selat Bengkalis.

3. Sebelah barat berbatasan dengan Selat Bengkalis.

4. Sebelah timur berbatasan dengan Kecamatan Bantan.

Sedangkan letak wilayahnya adalah:

1. $1^{\circ} 15^{\prime}$ Lintang Utara s/d $1^{\circ} 36^{\prime} 6^{\prime \prime}$ Lintang Utara

2. $102^{\circ} 00^{\prime}$ Bujur Timur s/d 102 $3^{\prime} 29^{\prime \prime}$ Bujur Timur.

Berdasarkan data dari Kantor Camat Bengkalis, luas wilayah kecamatan Bengkalis adalah $513 \mathrm{~km}^{2}$, dengan desa terluas adalah Desa Kelemantan yaitu $60 \mathrm{~m}^{2}$ atau sebesar $11,70 \%$ dari luas kecamatan Bengkalis seluruhnya. Sedangkan wilayah yang terkecil adalah Kelurahan Bengkalis Kota dengan luas $2 \mathrm{~km}^{2}$ atau $0,39 \%$ dari luas keseluruhan Kecamatan Bengkalis. Desa/kelurahan dengan jarak lurus terjauh dari Ibukota Kecamatan Bengkalis adalah Desa Sekodi dengan jarak lurus $60 \mathrm{~km}$, kemudian desa Kelemantan dengan jarak lurus $48 \mathrm{~km}$. Kecamatan Bengkalis terdiri dari 28 Desa dan 3 Kelurahan yang sudah berstatus definitif, dari 28 Desa tersebut yaitu: Sekodi, Palkun, Kelemantan Barat, Sungai Batang, Ketam Putih, Pematang Duku Timur, Pematang Duku, Penebal, Temeran, Damai, Penampi, Kuala Alam, Sungai Alam, Air Putih, Senggoro, Wonosari, Kelapapati, Pedekik, Pangkalan Batang, Pangkalan Batang Barat, Sebauk, Senderak, Teluk Latak, Meskom, Simpang Ayam, Prapat Tunggal, Kelebuk, dan
Kelemantan Barat. Dan 3 Kelurahan yaitu: Kelurahan Rimba Sekampung, Bengkalis Kota, dan Damon (Pemerintah Kabupaten Bengkalis, 2019).

Kelurahan Rimba Sekampung mempunyai luas $\pm \mathrm{km}^{2}$, bagian Utara berbatasan dengan Desa Wonogiri, bagian Seelatan berbatasan dengan Selat Bengkalis, bagian barat berbatasan dengan Kelurahan Kota Bengkalis, bagian Timur bersebelaan dengan Desa Senggoro, dengan jumlah kelapa keluarga $1.398 \mathrm{KK}$ dan jumlah penduduk 5.626 orang. Mata pencarian penduduk Rimba sekampung 340 orang pedagang, 5 orang peternak, 423 orang PNS, 222 orang Honorer, 15 orang TNI, 10 orang Polri, 53 orang Karyawan Swasta, 250 orang Nelayan, 38 orang Buruh , 50 orang Pensiunan, dan 18 orang Jasa Pengaangkutan (ojek, bejak, dll). Penduduk dengan status ekonomi sejahtera yaitu $1.003 \mathrm{KK}$ dan prasejahtera berjumlah 395 KK (Pemerintah Kabupaten Bengkalis, 2019).

\section{METODE}

Kegiatan Pengabdian ini dilakukan di Kelurahan Rimba Sekampung pada hari sabtu tanggal 5 september 2020 jam 10.00-15.00 WIB. Kegaiatan ini menggunakan Masker, Sabun Cuci Tangan, Handsanitaizer dan sembako. kegaiatan ini terdiri dari 2 program yaitu pembagian masker, sabun cuci tangan dan handsanitaizer di Posko Check Point COVID-19 Kabupaten Bengkalis dan Pembagian Sembako di Kelurahan Rimba Sekampung. Dari jam 10.00-11.00 WIB pembagian masker, sabun cuci tangan, handsanitaizer di Posko Check Point bersama dengan Bapak dan Ibu Polisi dan jam 12.00-15.00 
WIB pembagian Sembako di 5 RW yang ada di Kelurahan Rimba Sekampung. Masker, sabun dan handsanitaizer diberikan pada setiap masyakat yang lewat, sembako diberikan kepada masyarakat yang kurang mampu di Kelurahan Rimba Sekampung yang mana telah dilakukan pendataan terlebih dahulu dengan Kelurahan Rimba Sekampung.

\section{HASIL DAN PEMBAHASAN}

Pembagian 40 masker, 26 sabun cuci tangan dan 16 handsanitazier dilakukan di posko check point COVID-19 Kabupaten Bengkalis bersama dengan Bapak dan Ibu Polisi. 40 masker mayoritas dibagian kepada masyarakat yang tidak menggunakan masker saat keluar rumah, 26 sabun cuci tangan dan 16 handsanitaizer dibagian kepada masyarakat yang tidak membawa antiz saat keluar rumah. Masker, sabun cuci tangan dan handsanitaizer dibagikan kepada pengendara mobil, motor, sepeda, becak, dan kepada petugas yang berjaga di posko.

Tabel 1 Distribusi masker, sabun cuci tangan dan handsanitaizer

\begin{tabular}{|c|c|c|}
\hline Masker & $\begin{array}{c}\text { Sabun Cuci } \\
\text { Tangan }\end{array}$ & Handsanitaizer \\
\hline 40 & 26 & 16 \\
\hline
\end{tabular}

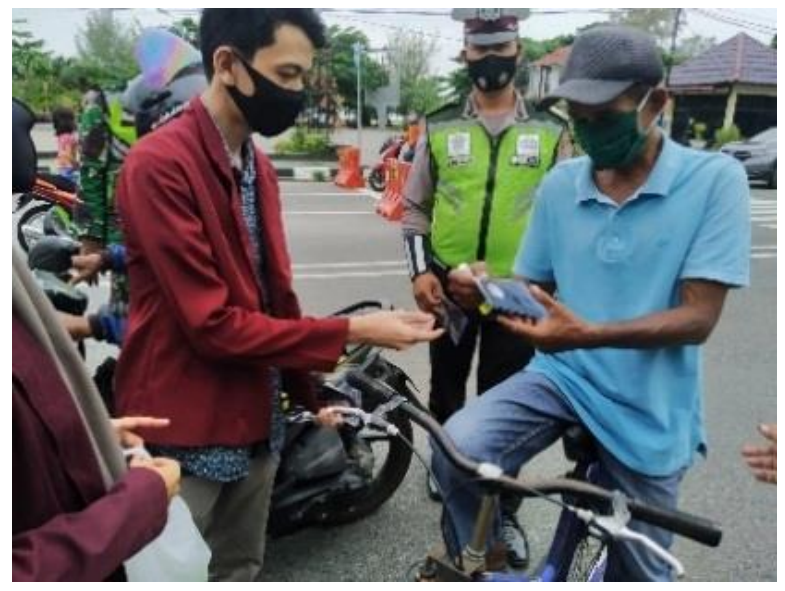

Gambar 1. Sosialisasi dan Pemberian Masker Kepada Masyarakat

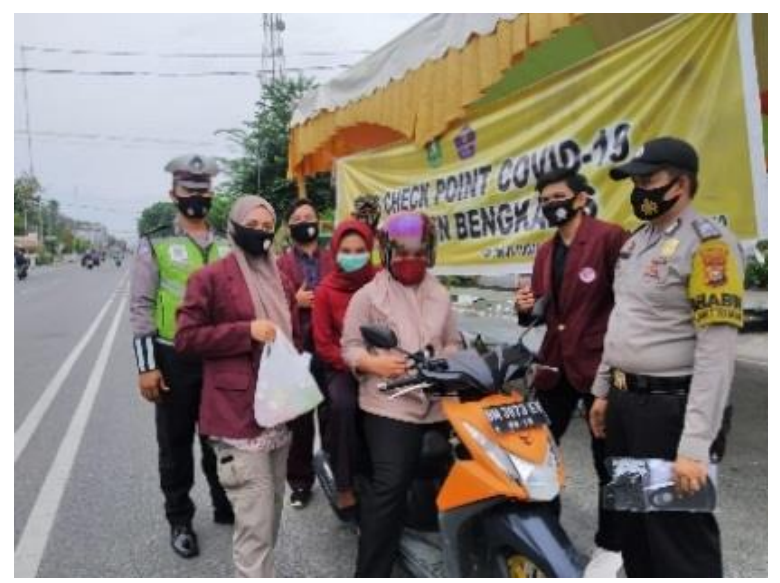

Gambar 2. Pembagian Masker, Sabun Cuci Tangan dan Handsanitaizer

Sebanyak 20 pcs sembako terdiri dari 1 beras, 1 minyak goring, 1 gula, 4 mie instan, 1 kotak teh dan 2 roti. Sembako dibagian di kelurahan Rimba Sekampung Kabputan Bengkalis pada jam 11.00-15.00 WIB. Yang mana terlebih dahulu mahasiswa dan kelurahan Rimba Sekampung memilih masyakarat yang layak untuk diberi sembako, sembako dibagian kemasyarakat kurang mampu yang terdapat pada $5 \mathrm{RW}$ di Kelurahan Rimba Sekampung, 5 sembako dibagian per RW. Sembako dibagian melalui rumah-kerumah, setiap rumah kelapa keluarga yang mendapatkan sembako akan ditempelkan 
411 Bantuan Sosial dan Edukasi Kesehatan bagi Masyarakat Pesisir yang Terdampak Sosial-Ekonomi Selama COVID-19 - Husni Mubarak, Fajar Anugerah Mubarak, Puspa Ningrum,Tyagita Widya Sari DOI : https://doi.org/10.31004/abdidas.v1i5.84

stiker kesehatan dan bahwasanya mahasiswa telah membagian sembako.

Tabel 2. Distirbusi Sembako

\begin{tabular}{|c|c|c|c|c|c|c|}
\hline & Beras & $\begin{array}{c}\text { Minyak } \\
\text { Goreng }\end{array}$ & Gula & $\begin{array}{c}\text { Mie } \\
\text { Instan }\end{array}$ & Roti & Teh \\
\cline { 2 - 7 } & $20 \mathrm{~kg}$ & $20 \mathrm{pcs}$ & $\begin{array}{c}20 \\
\mathrm{~kg}\end{array}$ & $\begin{array}{c}80 \\
\mathrm{pcs}\end{array}$ & $\begin{array}{c}80 \\
\mathrm{pcs}\end{array}$ & $\begin{array}{c}20 \\
\mathrm{pcs}\end{array}$ \\
\hline $\begin{array}{c}\text { Total } \\
\text { Sembako }\end{array}$ & \multicolumn{7}{|c|}{$20 \mathrm{pcs}$} \\
\hline
\end{tabular}
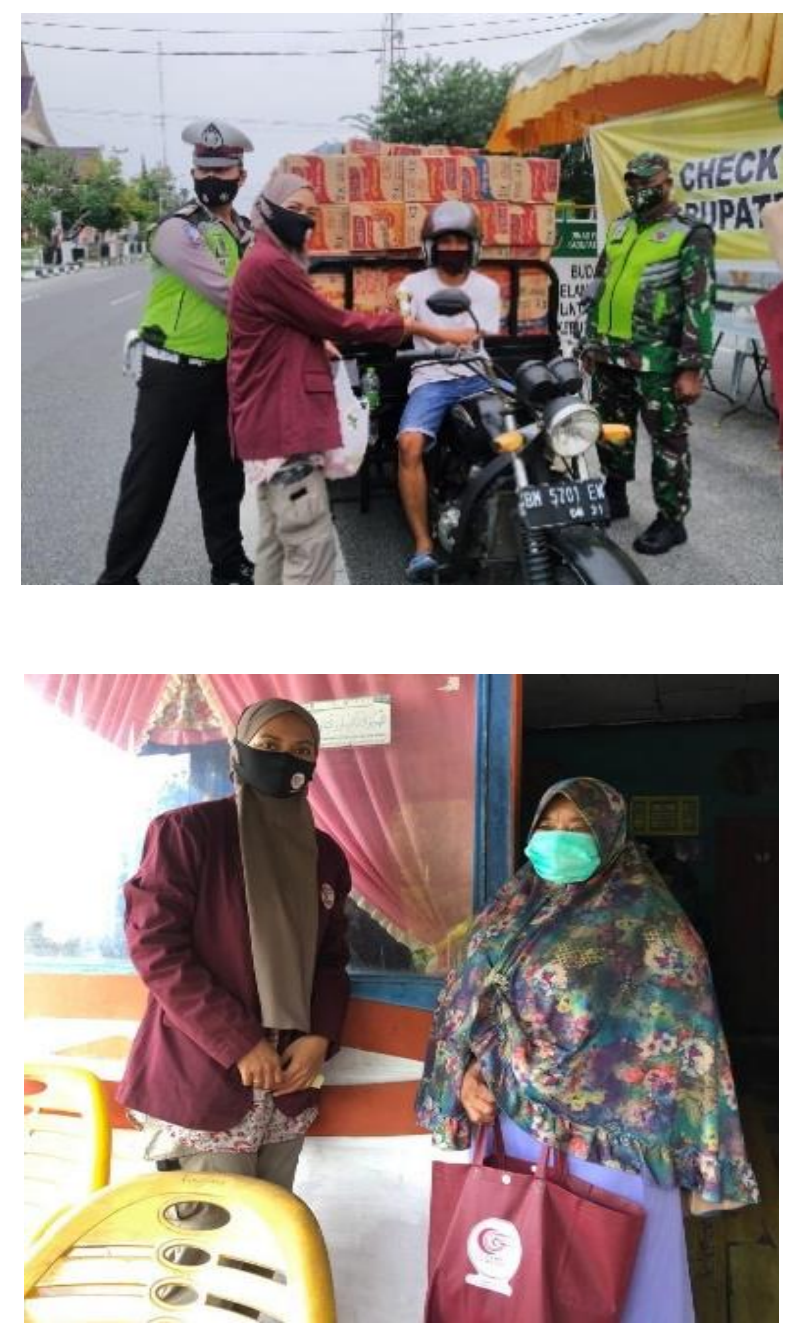

Gambar 3. Pembagian sembako

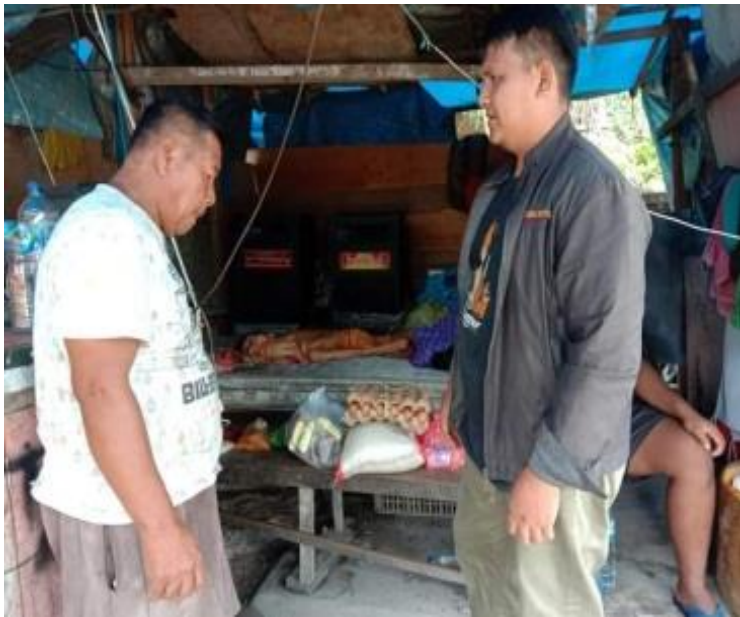

Gambar 4. Pembagian Sembako

\section{SIMPULAN}

Pengabdian kepada masyarakat dilakukan pada hari Sabtu, 5 September 2020 dari jam 10.0015.00 WIB. Kegaian PKM dilaksanakan di Kelurahan Rimba Sekampung Kabupaten Bengkalis, Yang terdiri dari 5 RW. Program kerja yang dijalankan mahasiswa telah direncanakan terlebih dahulu yaitu pembagian masker, sabun cuci tangan handsanitaizer di posko check point COVID-19 Kabupaten Bengkalis dan sembako di 5 RW Kelurahan Rimba Sekampung.

\section{UCAPAN TERIMA KASIH}

Pengabdian kepada masyarakat ini tidak bisa dijalankan bila tidak bekerja sama dengan pihak-pihak terkait. Dalam hal ini, tim pengabdian mengucapkan terima kasih kepada pihak perangakat kelurahan Rimba sekampung dari RT, RW dan masyarakat setempat serta pihak kepolisian dan satgas penanggulangan COVID-19 yang telah memberikan kesempatan kepada tim pengabdian untuk menjalankan kegiatan ini dengan lancar dan sukses. Tim pengabdian juga mengucapkan terima kasih kepada pihak 
412 Bantuan Sosial dan Edukasi Kesehatan bagi Masyarakat Pesisir yang Terdampak Sosial-Ekonomi Selama COVID-19 - Husni Mubarak, Fajar Anugerah Mubarak, Puspa Ningrum,Tyagita Widya Sari DOI : https://doi.org/10.31004/abdidas.v1i5.84

pemerintah kecamatan dan desa di wilayah pesisir utara dan selatan kabupaten Bengkalis, yang telah membantu memberikan data dan waktu untuk menjalankan kegiatan ini di wilayah administrasinya. Semoga kegiatan-kegiatan pengabdian pada masa mendatang tetap didasarkan pada kerja sama yang sudah terjalin dengan baik ini.

\section{DAFTAR PUSTAKA}

Beiu, C., Mihai, M., Popa, L., Cima, L., \& Popescu, M. N. (2020). Frequent hand washing for COVID-19 prevention can cause hand dermatitis: management tips. Cureus, 12(4).

Greenhalgh, T., Schmid, M. B., Czypionka, T., Bassler, D., \& Gruer, L. (2020). Face masks for the public during the covid-19 crisis. Bmj, 369.

Kartono, K. (2014). Pathologi sosial. Rajawali.

Matthay, M. A., Aldrich, J. M., \& Gotts, J. E. (2020). Treatment for severe acute respiratory distress syndrome from COVID19. The Lancet Respiratory Medicine, 8(5), 433-434.

Tapung, M. M., Regus, M., Payong, M. R., Rahmat, S. T., \& Jelahu, F. M. (2020). Bantuan sosial dan pendidikan kesehatan bagi masyarakat pesisir yang terdampak sosial-ekonomi selama patogenesis Covid-19 di Manggarai. Transformasi: Jurnal Pengabdian Masyarakat, 16(1), 12-26.

Telaumbanua, D. (2020). Urgensi Pembentukan Aturan Terkait Pencegahan Covid-19 Di Indonesia. QALAMUNA: Jurnal Pendidikan, Sosial, Dan Agama, 12(1), 59-70. 